\title{
Pengembangan Model Pembelajaran Konstruktivistik Ala To Ugi' (Analisis Kasus di SD Negeri Lalabata Kec.Tanete Rilau Kab. Barru)
}

\author{
Subaedah $^{\mathrm{a}, 1}$, Andi Banna ${ }^{\mathrm{a}, 2}$ \\ ${ }^{a}$ Universitas Muslim Indonesia \\ 1subaedah.subaedah@umi.ac.id; 2abanna@umi.ac.id
}

\begin{abstract}
Abstrak
Penelitian bertujuan mengembangkan Model Pembelajaran Konstruktivistik Berbasis Ala To Ugi' (PATU') di Sekolah Dasar Negeri Lalabata Kecamatan Tanete Rilau kabupaten Barru. Jenis penelitian adalah research and development (R\&D). Penelitian dilakukan dengan tahapan: 1) menganalisis tingkat kebutuhan peserta didik terhadap model pembelajaran konstruktivistik berbasis ala to ugi' (analisis kasus), 2) mendesain pengembangan model pembelajaran (research and development), 3) menghasilkan produk model pembelajaran konstruktivistik berbasis ala to ugi' (ditinjau dari segi ke-validan, ke-praktisan, ke-efektifan). Analisis data menggunakan deskrifptif kualitatif kuantitatif dengan program SPSS. Hasil penelitian menunjukkan: 1) analisis tingkat kebutuhan peserta didik terhadap model pembelajaran konstruktivistik ala to ugi' sangat dibutuhkan dalam memperbaiki karakter peserta didik mengingat pergeseran nilai-nilai moral sangat memprihatinkan, 2) desain pengembangan model pembelajaran terdiri dari: $\operatorname{sintak} \bar{x}=3.77$ (sangat valid), teori pendukung $\bar{x}=3.6$ (sangat valid), Sistem Sosial $\bar{x}=3.68$ (sangat valid), Sistem Reaksi (prilaku guru) $\bar{x}=3.78$ (sangat valid), Sistem Pendukung $\bar{x}=3.35$ (valid), Dampak Instruksional dan Dampak Pengiring $\bar{x}=3.67$ (sangat valid), Pelaksanaan Pembelajaran $\bar{x}=3.6$ (sangat valid), Lingkungan Belajar dan Tugas-Tugas pengelolaan $\bar{x}=3.75$ (sangat valid), Evaluasi $\bar{x}=3.55$ (sangat valid). Hasil analisis desain model PATUl nilai $\sum \bar{x}=3.64$ dapat dikatakan model PATU' memiliki kriteria SANGAT VALID

Hasil analisis uji coba.
\end{abstract}

Kata Kunci: Model, Pembelajaran, Konstruktivistik, Ala, To, Ugi'

\section{Pendahuluan}

Model pembelajaran merupakan salah satu faktor yang mampu menjadikan peserta didik membangun atau mengkonstruk pikiran sendiri, model pembelajaran juga mampu menjadikan peserta membentuk karakter dan lewat model pembelajaran pendidik dan peserta didik mampu menggali kearifan lokal yang dapat dijadikan sebagai tatanan etika dalam bermoral. Sebagai bangsa berbudaya kearifan lokal dijadikan sebagai acuan dalam mengukur etika bangsa Indonesia.

Pengaruh budaya asing yang ditiru peserta didik diakibatkan kurangnya pengenalan nilai-nilai budaya lokal sehingga tidak mengenali dan memahami budaya sendiri. Hal lain yang menjadi fenomena dalam proses pembelajaran adalah Pendidik kurang inovatif dalam penyajian materi ajar, sehingga proses pembelajaran berjalan monoton, pendidik kurang tertarik memperkenalkan budaya lokal, tidak menjadikan bahasa daerah sebagai pengantar dalam percakapan baik dalam ruangan maupun di luar ruangan, kurang peka terhadap karakter siswa yang mulai bergeser dari nilai dan norma agama. Dengan kondisi kelas yang kurang optimal, ditambah dengan kurang perhatian orang tua terhadap siswa (individu) maka pergeseran nilai-nilai moral dapat dilihat dan dirasakan sekarang ini.

Pergeseran nilai moral yang terjadi, (kasus di sekolah SD Negeri Lalabata) misal: peserta didik berbicara dengan pendidik tanpa ada rasa hormat atau rasa segan sedikitpun, kurang pangngadereng 
peserta didik dalam bersikap dan bertindak, kesantunan peserta didik terhadap pendidik tidak ada (kurang santun), bahasa bugis sebagai bahasa lokal tidak dipergunakan lagi sehingga budaya bugis semakin hilang, tidak mengenalkan budaya lokal pada peserta didik, bidang studi muatan lokal dianggap biasa oleh peserta didik, tidak ada batas antara pendidik dan peserta didik dalam hal berprilaku, dan hal lain yang menggambarkan nilai moral yang dimiliki oleh masyarakat bugis semakin terkikis.

Dengan demikian peneliti beranggapan bahwa dengan mengembangkan sebuah model pembelajaran yaitu model pembelajaran konstruktivistik berbasis ala to ugi' (Siri na Pesse) mampu membentuk karakter peserta didik, mengangkat kembali nilai-nilai ade' ugie, membumingkan kembali panggadereng nennia pangngampe madecengnge baik dalam lingkup sekolah, lingkup masyarakat, maupun dalam lingkup rumah. Adapun keutamaan penelitian ini adalah mengangkat nilai-nilai budaya to ugi' melahirkan model pembelajaran yang berbasis kebiasaan orang bugis yang merupakan adat budaya ugi'

\section{Metode Penelitian}

Jenis penelitian yang digunakan adalah merupakan penelitian dan pengembangan (Researt and Depelovment), bertujuan untuk mengembangkan model pembelajaran konstruktivistik berbasis Ala To Ugi' dengan kriteria ke-validan, ke-praktisan, dan ke-efektifan. Model pengembangan yang digunakan mengacu pada Borg and Gall dalam Sugiyono (2015: 166) dengan desain prosedur pengembangan model pembelajaran diilustrasikan pada gambar berikut:

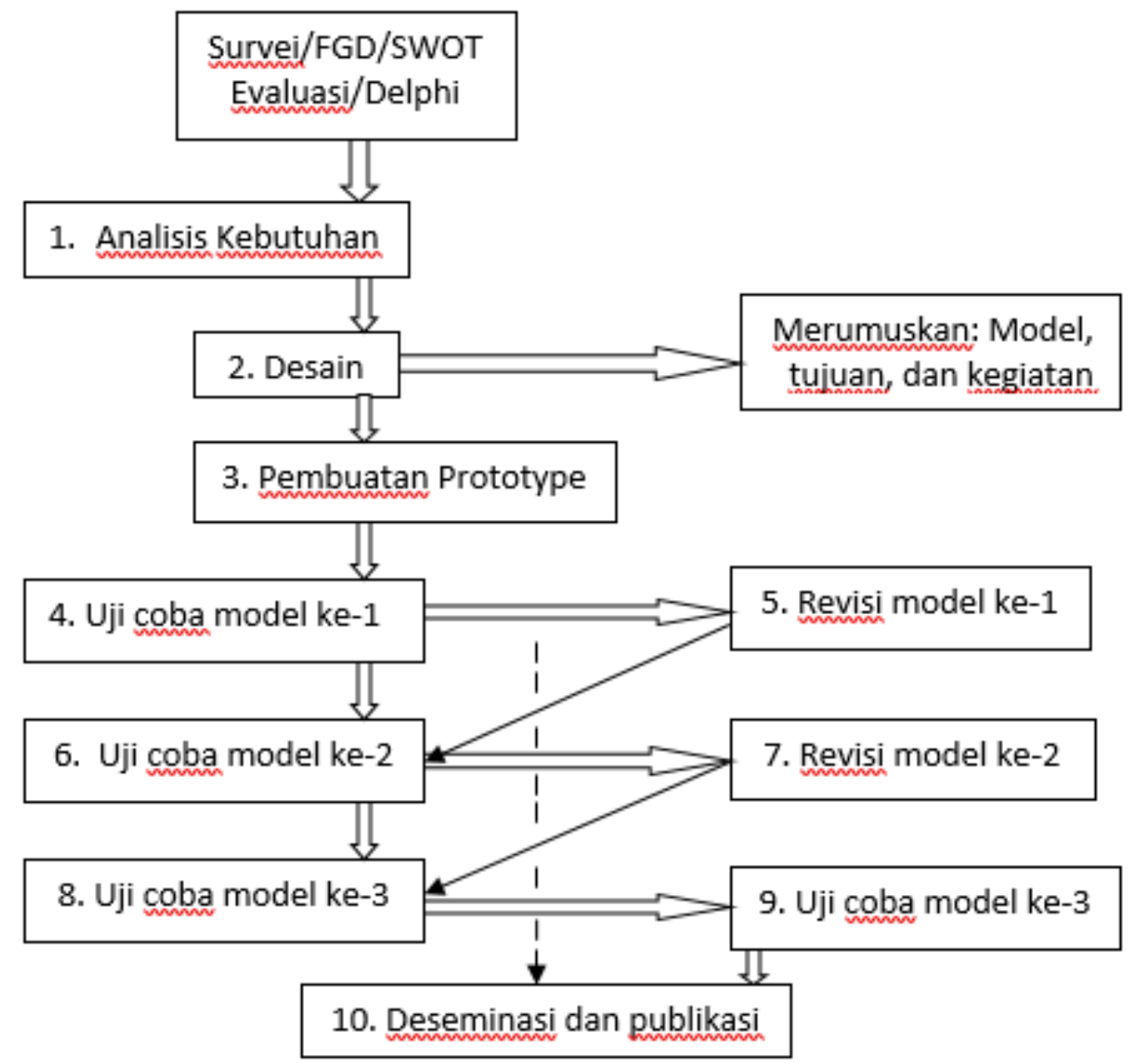

Gambar: Desain prosedur pengembangan model pembelajaran menurut Borg\&Goll 
Menurut Borg and Gall dapat disederhanakan dalam empat langkah namun Sukmadinata (2012: 184) penyederhanaan dapat menjadi tiga tahap pelaksanaan yaitu: studi pendahuluan, pengembangan model, uji model. Lebih jelasnya dapat dilihat dalam bagan berikut:

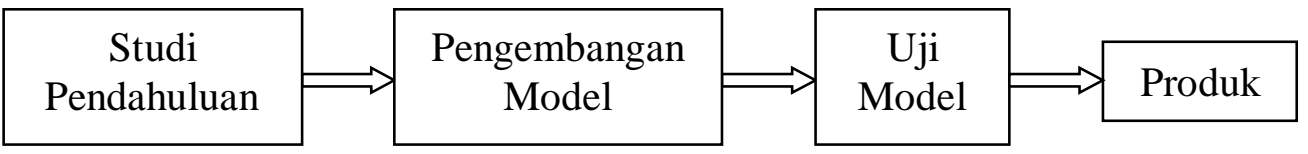

Bagan: Penyederhanaan Tahap Pelaksanaan R\&D

Seluruh kegiatan proses pengembangan model PATU beserta perangkat dan instrumen seperti telah terurai sebelumnya dapat digambarkan dalam satu diagram alur yang dimodifikasi dari model PK oleh Nurdin (2016) sebagai berikut:

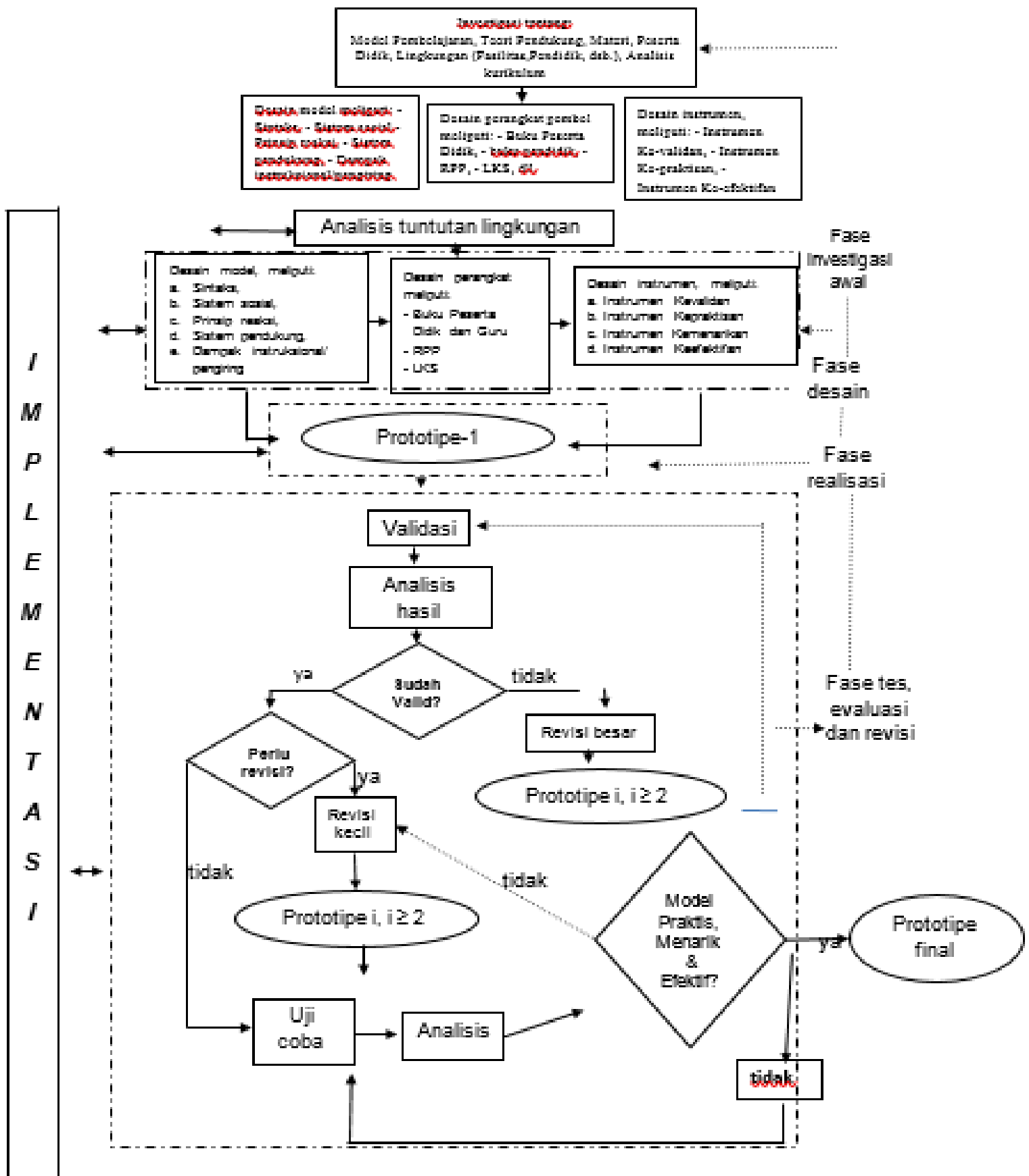

Gambar 3.1. Alur Kegiatan Pengembangan Model-PATU’ 
Keterangan :

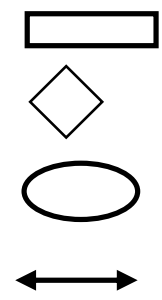

: Proses kegiatan

: Syarat/ kriteria produk

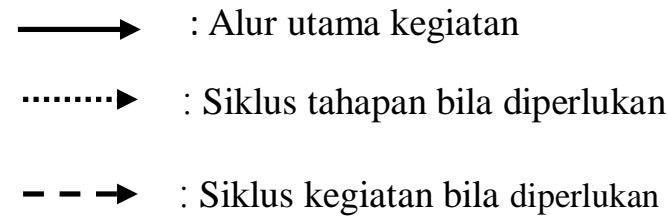

: Hasil kegiatan

$-\boldsymbol{-} \rightarrow \quad$ :Siklus kegiatan bila diperlukan

: Kegiatan timbal balik antara tahapan

pengembangan dengan implementasi

yang tengah berjalan

\section{Hasil Penelitian}

Hasil analisis yang diperoleh pada setiap fase pengembangan ditinjau dari ke-validan, kefektifan, dan ke-praktisan.

1. Penilaian validasi dan analisis model Patu' dapat dilihat pada tabel berikut:

\begin{tabular}{ccc}
\hline Aspek Model PATU' & $\begin{array}{c}\text { Skor Rata-rata } \\
\text { Penilaian }(\bar{x})\end{array}$ & Status \\
\hline Teori-Teori Pendukung & 3,77 & Sangat valid \\
Sintaks & 3,6 & Sanga valid \\
Sistem Sosial & 3,68 & Sangat valid \\
Prinsip Reaksi (Perilaku Guru) & 3,78 & Sangat valid \\
Sistem Pendukung & 3,35 & Valid \\
Dampak Instruksional dan Dampak & 3,67 & Sangat valid \\
Pengiring & 3,6 & Sangat valid \\
Pelaksanaan Pembelajaran & 3,75 & Sangat valid \\
Lingkungan Belajar & & Sangat valid \\
dan Tugas-Tugas Pengelolaan & 3,55 & Sangat valid \\
Evaluasi & 3,64 & \\
\hline Rata-rata Total & &
\end{tabular}

Tabel: Rangkuman Hasil Validasi Perangkat Pembelajaran Model PATU'

2. Analisis hasil uji coba dapat dilihat dalam table berikut:

a. Uji coba I: Hasil analisis untuk masing-masing komponen model PATU' dapat dilihat dalam tabel berikut:

Tabel: Hasil Analisis Keterlaksanaan Model PATU' Uji Coba Pertama

\begin{tabular}{cc|cc}
\hline Aspek Model PATU' & \multicolumn{2}{c}{$\begin{array}{c}\text { Hasil Pengujian } \\
\text { Kuantitatif }\end{array}$} & \multirow{2}{*}{$\begin{array}{c}\text { Hasil Pengujian } \\
\text { Kualitatif }\end{array}$} \\
\cline { 2 - 3 } & $\bar{x}$ & $\mathrm{R}$ & \\
\hline Sintaks & 1,52 & 100 & Terlaksana seluruhnya \\
Sistem Sosial & 1,57 & 100 & Terlaksana seluruhnya \\
Prinsip Reaksi (Perilaku pendidik) & 1,59 & 100 & Terlaksana seluruhnya \\
Sistem Pendukung & 1,95 & 92,06 & Terlaksana seluruhnya \\
\hline Rata-rata Total & 1,66 & 98,06 & Terlaksana seluruhnya \\
\hline
\end{tabular}


b. Uji Coba Ke -II: Hasil análisis pada komponen model PATU' dalam tabel berikut: Tabel: Hasil Analisis Komponen Model PATU'

\begin{tabular}{cc|cc}
\hline \multirow{2}{*}{ Aspek Model POKM } & \multicolumn{2}{c}{$\begin{array}{c}\text { Hasil Pengujian } \\
\text { Kuantitatif }\end{array}$} & $\begin{array}{c}\text { Hasil Pengujian } \\
\text { Kualitatif }\end{array}$ \\
\cline { 2 - 3 } & $\bar{x}$ & $\mathrm{R}$ & \\
\hline Sintaks & 1,67 & 100 & Terlaksana seluruhnya \\
Sistem Sosial & 1,58 & 100 & Terlaksana seluruhnya \\
Prinsip Reaksi (Perilaku Guru) & 1,72 & 100 & Terlaksana seluruhnya \\
Sistem Pendukung & 1,98 & 100 & Terlaksana seluruhnya \\
\hline Rata-rata Total & 1,74 & 100 & Terlaksana seluruhnya \\
\hline
\end{tabular}

Tabel: Hasil Uji- t Berpasangan Data Residual Hasil Pre-test dan Hasil Pos-test

\begin{tabular}{|c|c|c|c|}
\hline \multicolumn{2}{|c|}{ Hasil Uji Coba Model PATU' } & \multicolumn{2}{|c|}{ Satu Sampel } \\
\hline \multirow{5}{*}{$\begin{array}{l}\text { Residual }=\text { Pos- } \\
\text { test }- \text { Pre-test }\end{array}$} & Rerata & & 2,60 \\
\hline & Standar Deviasi & & 3,174 \\
\hline & Standar Kesalahan Rerata & & 0,635 \\
\hline & \multirow{2}{*}{$\begin{array}{l}\text { Selang kepercayaan dengan } \\
\text { tingkat kepercayaan } 95 \%\end{array}$} & Batas Bawah & 1,33 \\
\hline & & Batas Atas & 3,95 \\
\hline
\end{tabular}




\section{DAFTAR PUSTAKA}

Chujaemah Nurul, Yuliana Septi, Utaminingsi Suci, (2012) "Penggunaan Pendekatan Konstruktivistik dalam Peningkatan Hasil Belajar Matematika Materi Bangun Ruang". nurulchujaemah@yahoo.co.id

Goleman Daniel, (2011), Emotional Intellegence (Kecerdasan Emosional, Mengapa EI lebih penting dari EQ). Jakarta: Gramedia Pustaka Utama

Lickona Thomas, (2013). Educating for Character (Mendidik untuk Membentuk Karakter). Jakarta: Bumi Aksara

Mulyatiningsi Endang, (2013). "Analisis Model Pendidikan Karakter untuk Usia Anak, Remaja, dan Dewasa". endang_mulyati ningsi@yahoo.com

Mulyatiningsih Endang, (2014). Metode Penelitian Terapan Bidang Pendidikan. Bandung: Alphabeta

Setyosari Punaji, (2010). Metode Penelitian Pendidikan dan Pengembangan. Jakarta: Kencana Prenada Media Group

Sukardi, (2013). Metodologi Penelitian Pendidikan (Kompetensi dan Prakteknya). Jakarta: Bumi Aksara

Sultoni Ahmad, Hilmi Saufan Hubbi, (2013). Pembelajaran Sastra Berbasis Kearifan Lokal sebagai Upaya Optimalisasi Pendidikan Karakter Kebangsaan menuju Masyarakat Ekonomi ASEAN. ahmadsultoni31@yahoo.co.id

Suastra I Wayan, (2013). Model Pembelajaran Sains Berbasis Budaya Lokal dalam Mengembangkan Potensi Dasar Sains dan Nilai Kearifan Lokal Bali di SMP Negeri. iwayansuastra61@gmail.com

Warpala Sukara I Wayan, Subagia I Wayan, Suastra I Wayan. (2010). "Pengembagan Bahan ajar Berbasis Kearifan Lokal untuk Mata Pelajaran Sains SMP", dalam Jurnal Penelitian dan Pengembangan Pendidikan, Vol. 4, No. Desember

Zubaedi, (2012). Desain Pendidikan Karakter (Konsepsi dan Aplikasinya dalam Lembaga Pendidikan). Jakarta: Kencana Prenada Media Group 